\title{
Evaluation of Actual Creep Length Under Heading up Structures Aprons
}

\author{
M.A. El Mollaa, N.Y. Saadb, ${ }^{*}$, and G.S. Ezizahb \\ ${ }^{a}$ Civil Engineering Department, Higher Technological Institute, Cairo, Egypt. \\ ${ }^{b}$ Irrigation and Hydraulics Department, Faculty of Engineering, Ain Shams University, Cairo, Egypt.
}

Received 13 January 2016; Accepted 26 November 2017

\begin{abstract}
In this paper a 2D finite element model (SEEP2D) is implemented to study the actual head loss along the sheet piles fixed at the ends of an apron of a heading up structure. Different scenarios for the thickness of the pervious layer under the apron, the length of the apron and the depths of the upstream and downstream sheet piles are studied. Results show that assuming the outer and inner faces of the sheet piles have the same weight for estimating the creep length while designing aprons of hydraulic structures is weak. Design equations for the actual head loss along the outer and inner faces for both the upstream and downstream sheet piles are driven. These equations can be used as a tool in the practical design for aprons of heading up structures formed on pervious soil and provided with upstream and downstream sheet piles at its ends.
\end{abstract}

Keywords: SEEP2D; Seepage; Heading-up structures; Sheet piles; Creep length.

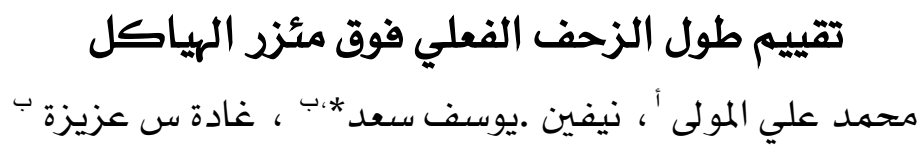

الملخص: يو هذه الورقة البحثية، يتم تطبيق نهوذج لعنصرالطبقة التحتية المحدود (SEEP2D) لدراسة الفقدان الفعلي للقمة المتواجدة على طول أكوام الطبقات المثبتة يٌّ نهايات مئزر الهياكل العلوية ويتم دراسة سيناريوهات مختلفة لسمك الطبقة

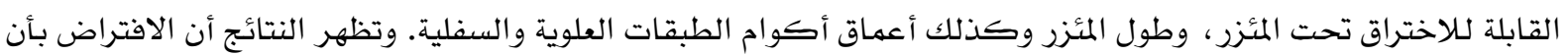
الأوجه الخارجية والداخلية لأكوام الطبقات لها نفس وزن طول الزحف المقدر عندما يكون تصميم مآزر الهياكل الهيدروليكية هو إفتراض ضعيف .ويتم عمل معادلات التصميم للخسارة الفعلية للقمة على طول الأوجاه الخارجية والداخلية

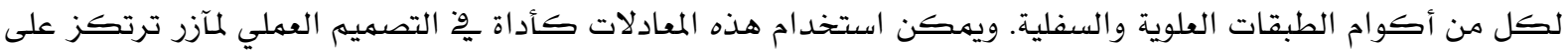
هياكل متكونة على تربة قابلة للاختراق، ومزودة بأكوام من الطبقات العلوية والسفلية وِّ نهاياتها. الكلمات المفتاحية: تسرب، هياكل علوية ، طبقات متراكمة، طول الزحف.

* Corresponding author's email: neveen_yousif@hotmail.com 


\section{Notations}

The following symbols are used in this paper.

$\mathrm{d}_{1}$

Depth of upstream sheet pile (L);

$\mathrm{d}_{2}$

Depth of downstream sheet pile (L);

ho1

Head lost along the outer face of upstream sheet pile (L);

$\mathrm{h}_{\mathrm{O} 2}$

Head lost along the outer face of downstream sheet pile (L);

$\mathrm{h}_{11}$

Head lost along the inner face of upstream sheet pile (L);

$h_{12}$

Head lost along the inner face of downstream sheet pile (L);

g

Gravitational acceleration $\left(\mathrm{L} / \mathrm{T}^{2}\right)$;

$\mathrm{H}$

Head difference between upstream and downstream the apron (L);

K

Hydraulic conductivity of the homogeneous pervious stratum (L/T);

L

Horizontal distance between the upstream and downstream sheet

Piles (L);

$\mathrm{P}_{1}$

Head at point (1) (L);

$\mathrm{P}_{2}$

Head at point (2) (L);

$\mathrm{P}_{3}$

Head at point (3) (L);

$\mathrm{P}_{4}$

Head at point (4) (L);

$\mathrm{P}_{5}$

Head at point (5) (L);

$\mathrm{P}_{6}$

Head at point (6) (L);

$\mathrm{T}$

Thickness of pervious stratum under the apron (L);

$\rho$

Density of seeping water $\left(\mathrm{M} / \mathrm{L}^{3}\right)$; 


\section{Introduction}

Seepage is one of the most important factors that affects the stability of a heading-up structure. Using sheet piles under the aprons of heading-up structures increases the percolation length, decreases the hydraulic gradient, and hence provides more safety against piping and uplift under the apron of a structure. Figure (1) represents the concept of creep length and hydraulic gradient diagram.

Numerical methods (Finite Element, Finite Difference, Boundary Element and Total Variation Diminishing Method ) can be used to solve seepage problems with different degrees of complexities and accuracies Harr (1962); Serge Leliavsky (1965); U.S. Army Corps of Engineers (1986). Ahmed and Ellboudy (2010) carried out a number of numerical analysis to study the influence of different sheet pile configurations on the seepage losses, the uplift force on the apron, and the exit gradient at the end of the apron. They concluded that driving a sheet pile under a hydraulic structure that surrounds the downstream floor apron from all sides, has greatly reduced the exit gradient at the end toe of the floor. However, this was accompanied with some increase in the uplift force. Ahmed (2011) studied different sheet piles configurations and flow through canal banks. Kamble et al. (2014) described the potential of different approaches such as geological and geotechnical methods, dam instrumentation, geophysical methods, tracer techniques, nuclear logging and mathematical modeling for monitoring, detecting and analyzing seepage in hydraulic structures.

Three dimensional modeling techniques (3D) have recently been attempted to study seepage beneath and around hydraulic structures for different purposes. Eftekhar and Barani (2013) used SEEP3D to pinpoint the best locations of cutoff walls. They revealed that a cutoff wall installed at the lower toe of the structure eliminates piping and the one located at the upper toe reduces the uplift pressure. Guerra et al. (2012) suggested that complex junctions in levee systems (i.e. 90 degrees bend in the levee alignment as well as a box culvert through the levee) should be studied using 3D models. Koltuk and Iyisan (2013) compared between the 2D and 3D modeling techniques in studying a rectangular shaped cofferdam taking into account the vertical anisotropy of the permea- bility of soil layers. He concluded that the difference between the values obtained from 2D and $3 \mathrm{D}$ analysis decreased with increasing the length to width ratio of the cofferdam. Gad et al. (2016) conclude that 3D simulations are essential in studying seepage under large dams especially in complicated 3D configurations and lateral heterogeneity.

El Tahan and ElMolla (2013) used the electric analogue method to investigate models of hydraulic structures' aprons provided with two equal cutoffs. They investigated the efficiency of both faces (outer and inner) of these cutoffs. They concluded that the estimation of the percolation length under the hydraulic structure must consider a weighted length factor for various faces of the cut-offs.

SEEP2D is a finite element program that has been applied in many researches to study seepage and has proved to be an efficient tool for seepage analysis (Ozkan 2003; Noori and Ismaeel 2011; Anas 2012; Aboulatta et al. 2014).

ElMolla (2001) used SEEP2D to investigate seepage under the aprons of heading up structures provided with a single cut-off.

In this paper, SEEP2D is used to investigate the actual head loss along the sheet piles fixed at the ends of an apron of a heading up structure formed on a pervious soil. Equations of the relation between head loss along both faces (outer and inner) of upstream (U.S.) and downstream (D.S.) sheet piles and the involved variables will be driven to be used in creep length designing purpose which, to the best of the authors' knowledge, has not been covered in the literature yet.

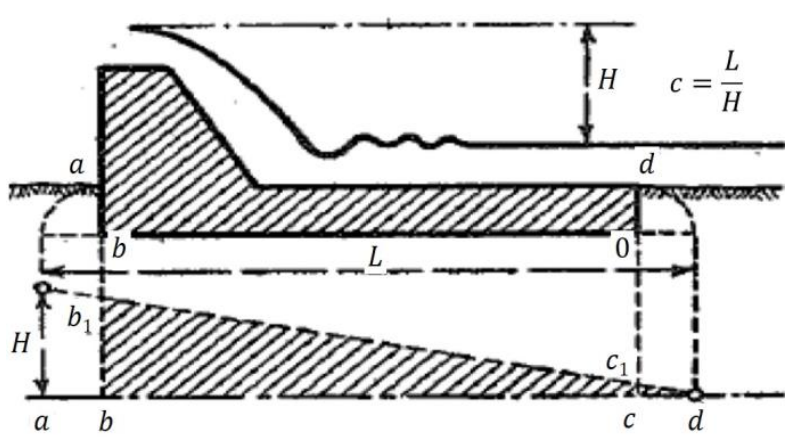

Figure 1. Line of creep and hydraulic gradient diagram (after Serge Leliavsky, 1965). 
In this study sensitivity analysis for the variables involved in the problem as well as different scenarios for the thickness of pervious layer under the apron, the length of the apron, the depths of the upstream and downstream sheet piles, and the hydraulic conductivity are studied.

\section{Dimensional Analysis}

In the present study, all the variables involved in the problem can be expressed as (Refer to Fig. (2)):

$\mathbf{F}\left(\boldsymbol{H}, \boldsymbol{d}_{1}, \boldsymbol{d}_{2}, \mathbf{L}, \mathbf{T}, \boldsymbol{k}, \mathrm{r}, \boldsymbol{g}, \boldsymbol{P}_{1}, \boldsymbol{P}_{2}, \boldsymbol{P}_{3}, \boldsymbol{P}_{4}, \boldsymbol{P}_{5}, \boldsymbol{P}_{6}=0\right.$

where: $\mathrm{H}=$ Head difference between upstream and downstream the apron; $\mathrm{d}_{1} \& \mathrm{~d}_{2}=$ depth of upstream and downstream sheet pile respectively; $\mathrm{L}=$ Horizontal distance between the upstream and downstream sheet piles; $\mathrm{T}=$ Thickness of pervious stratum under the apron; $\mathrm{K}=$ Hydraulic conductivity of the homogeneous pervious stratum under the apron; $\rho=$ Density of seeping water; $g=$ Gravitational acceleration; $\mathrm{P}_{1}, \mathrm{P}_{2}, \mathrm{P}_{3}, \mathrm{P}_{4}, \mathrm{P}_{5}, \mathrm{P}_{6}=$ Head at points $(1,2,3,4,5,6)$.

Applying Buckingham's $\Pi$ Theorem, the relationship between the above different variables can be presented as follow:

$\Phi\left(\frac{d_{1}}{d_{2}}, \frac{L}{T}, \frac{T}{d_{2}}, \frac{k}{\sqrt{g * H}}, \frac{h_{O I}}{h_{I 1}}, \frac{h_{O 2}}{h_{I 2}}\right)=0$

where

$\frac{h_{O 1}}{h_{I 1}}=\frac{P_{1}-P_{2}}{P_{2}-P_{3}}$

and

$\frac{h_{O 2}}{h_{I 2}}=\frac{P_{5}-P_{6}}{P_{4}-P_{5}}$
$\mathrm{h}_{\mathrm{O} 1} / \mathrm{h}_{\mathrm{I} 1}=$ the ratio between the head loss along the outer face and the inner face of the U.S sheet pile, and $h_{\mathrm{O} 2} / h_{12}=$ the ratio between the head loss along the outer face and the inner face of the D.S sheet pile.

\section{Description of the Model}

The SEEP2D software was developed by the United States Army Engineer Waterways Experiment Station to model a variety of problems involving seepage. The governing equation used in this model is the Laplace equation. Laplace equation is the governing differential equation for two dimensional, steady state incompressible, isotropic flow in the xy plane which is

$\frac{\partial^{2} h}{\partial x^{2}}+\frac{\partial^{2} h}{\partial y^{2}}=0$

where $\mathrm{h}$ is the head at any point in the flow domain.

Transient or time varying problems and unconfined plan view (aerial) models cannot be modelled using SEEP2D. SEEP2D allows for different hydraulic conductivities along the major and minor axes (anisoropic conditions) to be defined. Heterogeneous models can be created by specifying different values of hydraulic conductivity for the elements representing the different layers or regions. Post-processing includes contouring of the total head (equipotential lines), drawing flow vectors, and computing flow potential values at the nodes. These values can be used to plot flow lines together with the equipotential lines (i.e. flow nets). The phreatic surface can also be displayed (SEEP2D Primer 1998).

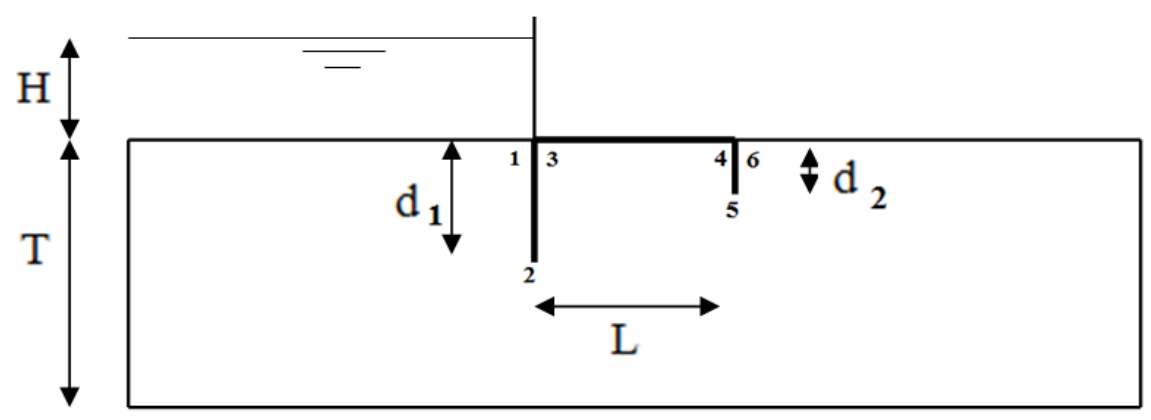

Figure 2. The variables involved in the problem. 
In a typical modelling problem involving the SEEP2D software, a series of tasks are performed in a specific sequence as follows: 1 . Mesh generation 2. Setting boundary conditions; 3. SEEP2D execution; and 4. Postprocessing the output.

\section{Model Application}

The dimensions for different variables as recommended from a previous study Ezizah et al. (2000) are as follows:

$\mathrm{d}_{1}=(0.2 \text { to } 0.6)^{*} \mathrm{~L}, \mathrm{~d}_{2} / \mathrm{d}_{1}=(0.7$ to 0.2$), \mathrm{H} / \mathrm{L}=$ $(1 / 2,1 / 3,1 / 6,1 / 8), \mathrm{d}_{1} / \mathrm{T}=(0.1$ to 0.5$)$ or $\mathrm{T}=$ $1.5 \mathrm{~L}$.

The model consists of a heading up structure formed on a pervious homogeneous isotropic soil layer with thickness $\mathrm{T}(\mathrm{T}=15,22.5,30,60 \mathrm{~m})$. Two values of head difference $(\mathrm{H})$ between U.S and D.S the structure are considered $(\mathrm{H}=3,7 \mathrm{~m})$. The apron of the structure is of length $L(L=10$, $15,20 \mathrm{~m}$ ) and provided with two sheet piles at its ends driven to depths $d_{1}$ and $d_{2}$, where $d_{1}$ is the depth of the U.S sheet pile $\left(\mathrm{d}_{1}=3,4,5,6 \mathrm{~m}\right)$ and $d_{2}$ is the depth of the D.S sheet pile $\left(d_{2}=1.5\right.$, $2.5 \mathrm{~m})$.

Figure (3) shows a finite element mesh used for one of the simulations. Figure (4) shows a Sample of flow net obtained from SEEP2D (SEEP2D output).

\subsection{Boundary Conditions}

All external edges of the problem were modelled as impermeable boundaries including the upstream and downstream edges and the bottom of the problem. The apron of the hydraulic structure was also modelled as impermeable boundary. All upstream nodes of the structure in the canal bed were allocated a prescribed head $(\mathrm{H})(\mathrm{H}=3$ or $7 \mathrm{~m})$. Nodes in the canal bed downstream of the structure were assigned a prescribed head value of zero.

\subsection{Calibration and Verification of the Model}

Experimental readings of a previous study El Tahan and ElMolla (2013) were used to calibrate the model to choose a reasonable cell size and check that the input data were entering correctly. Three different mesh cell sizes were

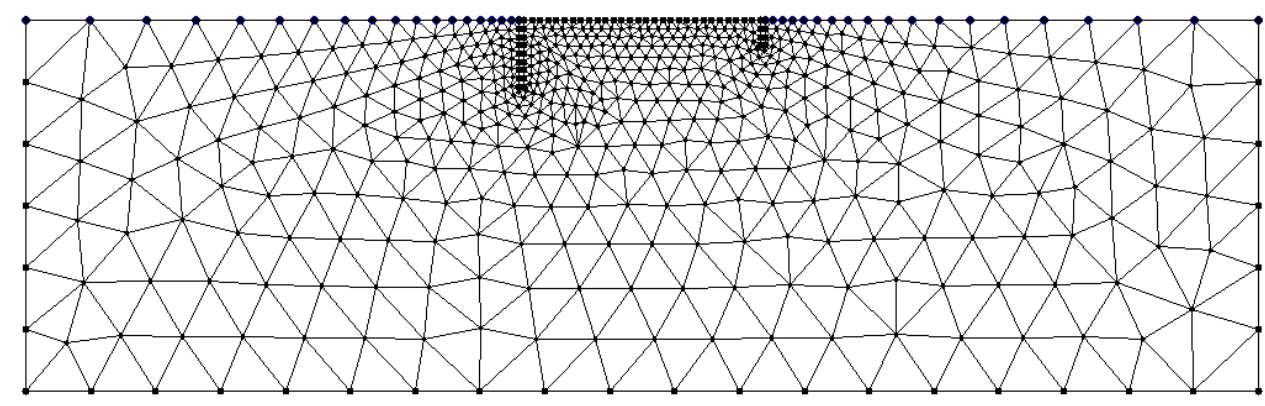

Figure 3. Sample of SEEP2D mesh.

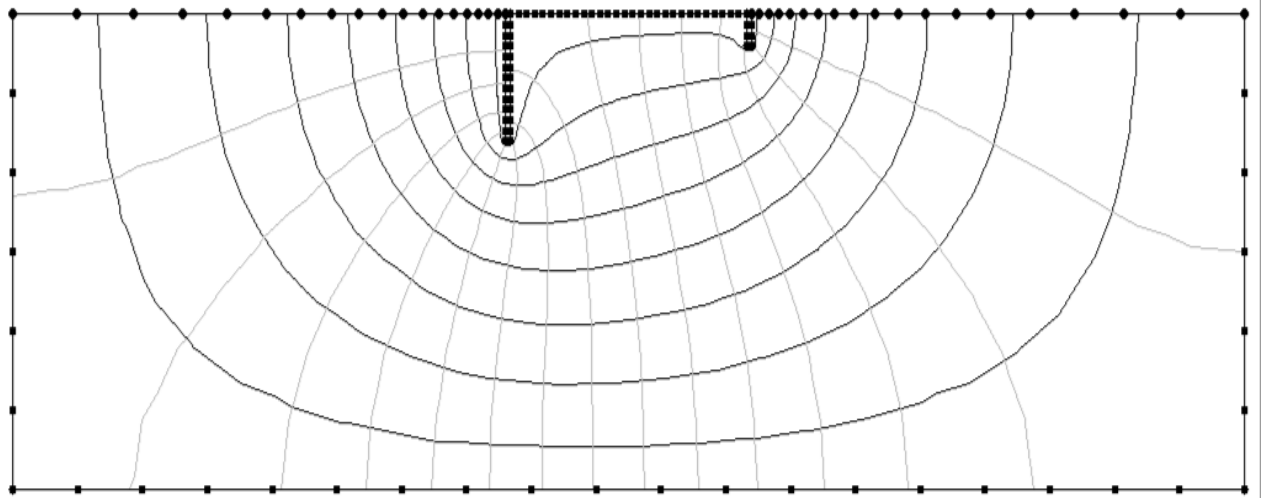

Figure 4. Sample of flow net obtained from SEEP2D (SEEP2D output). 
used in order to calibrate the model in an attempt to match the experimental data. Then Mesh would be generated as smaller mesh cell sizes were chosen around and between the two sheet piles in order to accurately show the changes in head when using sheet piles. The experimental study includes two equal sheet piles under the apron of the heading up structure.

Two values of $\mathrm{H}$ were used $\mathrm{H}=3,6 \mathrm{~m}$, $\mathrm{L}$ was taken 15 and $20 \mathrm{~m}$ while $\mathrm{d}_{1}$ and $\mathrm{d}_{2}$ were taken $5 \mathrm{~m}$.

Figure (5) illustrates a sample of the model calibration using the chosen best cell size, which represents the head readings at points P1 to P6. It is obvious that there is a good matching between the experimental readings and the numerical model.

Using the calibrated mesh size, the model is verified by another set of electric analogue experimental readings (AboulAtta et al. 2010). The length of apron $\mathrm{L}=19 \mathrm{~m}$, the depth of the U.S and D.S sheet pile $d_{1}=5 \mathrm{~m}, \mathrm{~d}_{2}=2.5 \mathrm{~m}$. Two values for $\mathrm{H}(3,7.5 \mathrm{~m})$ were used. Figure (6) illustrates a sample of the model verification, which represents the head readings at points P1 to P6. It is obvious that there is a good matching between the experimental readings and the numerical model.

\subsection{Sensitivity Analysis}

Sensitivity analysis was carried out in order to find the most effective parameters for different variables. From the sensitivity analysis it is noticed that the variables which have the biggest effect on the head loss ratio along the upstream sheet pile are the thickness of pervious soil layer under the apron $(\mathrm{T})$ and the depth of U.S sheet pile $\left(\mathrm{d}_{1}\right)$.

For the D.S sheet pile, it is noticed that the thickness of pervious soil layer under the apron $(\mathrm{T})$ and the depth of downstream sheet pile $\left(\mathrm{d}_{2}\right)$ have the biggest effect on the results. Moreover, the head difference $\mathrm{H}$ and the hydraulic conductivity $\mathrm{K}$ have negligible effect on the ratio of the head lost along the faces for the both sheet piles.

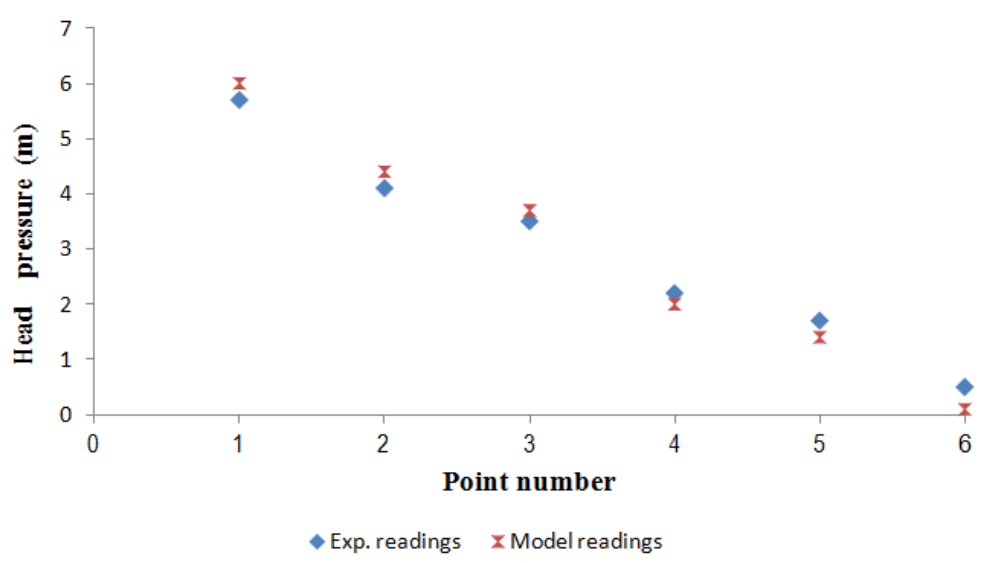

Figure 5. Sample of model calibration $\mathrm{H}=6 \mathrm{~m}, \mathrm{~L}=20 \mathrm{~m}, \mathrm{~d}_{1} \& \mathrm{~d}_{2}=5 \mathrm{~m}$.

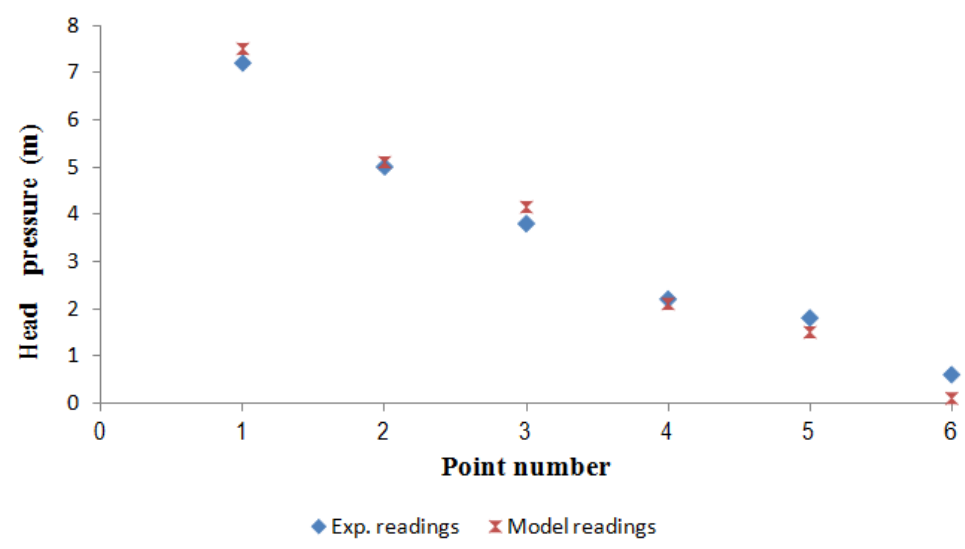

Figure 6. Sample of model verification $H=7.5 \mathrm{~m}, \mathrm{~L}=19 \mathrm{~m}, \mathrm{~d}_{1}=5 \mathrm{~m}, \mathrm{~d}_{2}=2.5 \mathrm{~m}$. 
Figures (7) and (8) show the effect of each variable on the ratio between the head loss along the outer face and the inner face of U.S and D.S sheet piles respectively $\left(h_{\mathrm{O}} / h_{\mathrm{I}}\right)$.

\section{Results Analysis}

The readings obtained from SEEP 2D are investigated and analyzed in order to determine the effect of changing the length of apron, the thickness of soil layer and the depths of upstream and downstream sheet piles on the ratio between the head loss along the outer and the inner faces for both the upstream and downstream sheet piles.

Plotting the head loss ratio along the outer face and the inner face for the U.S sheet pile $\left(\left(h_{\mathrm{O} 1} / h_{I 1}\right)\right.$ against the depths ratio of U.S and the
D.S sheet pile $\left(\mathrm{d}_{1} / \mathrm{d}_{2}\right)$ for different values of $\left(T / d_{2}\right)$ is shown in Fig. (9). It is noticed that $\left(h_{01} / h_{11}\right)$ decreases with the increase of the ratio between $\left(d_{1} / d_{2}\right)$ for all $\left(T / d_{2}\right)$ values. So, the efficiency of the inner face of the U.S sheet pile improves by $8-16 \%$ with increasing the ratio $\mathrm{d}_{1} / \mathrm{d}_{2}$. Also, it is obvious that the ratio of $\left(T / d_{2}\right)$ is directly proportional to $\left(\mathrm{h}_{\mathrm{O} 1} / \mathrm{h}_{\mathrm{I}}\right)$. That means the efficiency of the inner face of U.S sheet pile improves by decreasing the values of $\mathrm{T} / \mathrm{d}_{2}$. Moreover, changing $\mathrm{T} / \mathrm{d}_{2}$ affects $\mathrm{h}_{\mathrm{O} 1} / \mathrm{h}_{\mathrm{I}}$ values for bigger values of $d_{1} / d_{2}$ than smaller ones.

From Fig. 9, it was found that the best relation between $\left(h_{01} / h_{11}\right)$ and $\left(d_{1} / d_{2}\right)$ is given by linear equation with correlation equal $\mathrm{R}$ ( $\mathrm{R}$ measures the strength of the relationship between variables):

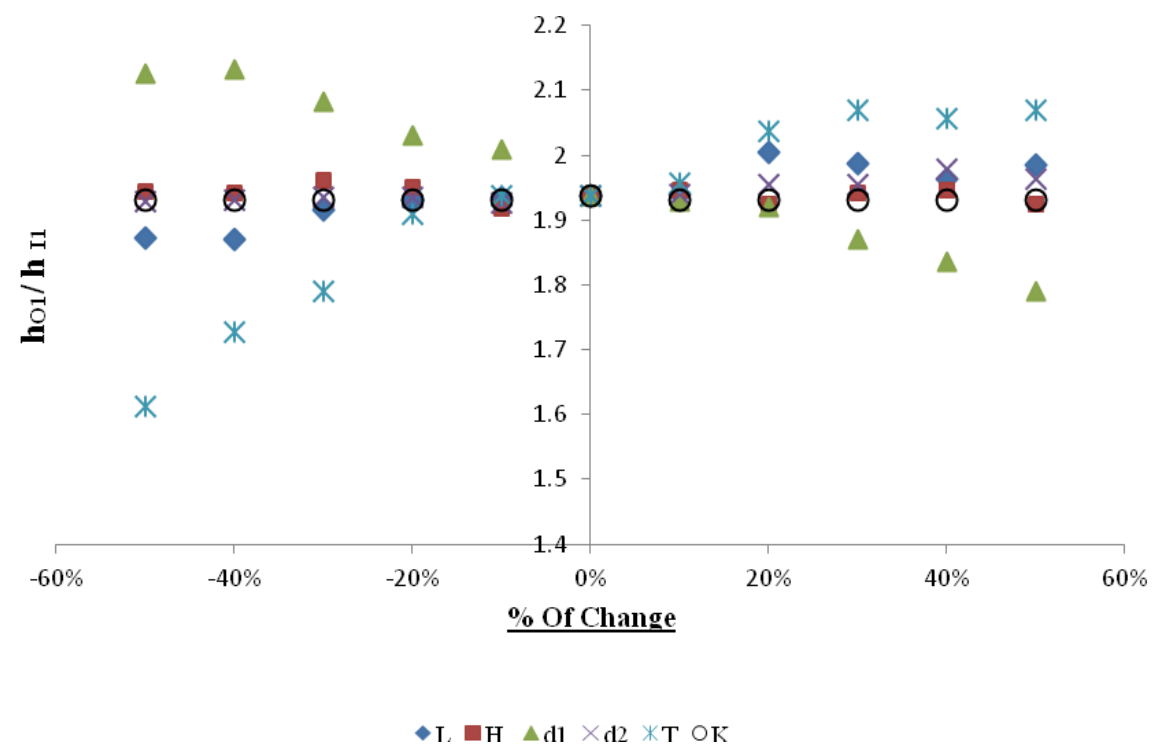

Figure 7. Effect of each variable on the ratio $\left(h_{\mathrm{O} 1} / h_{11}\right)$.

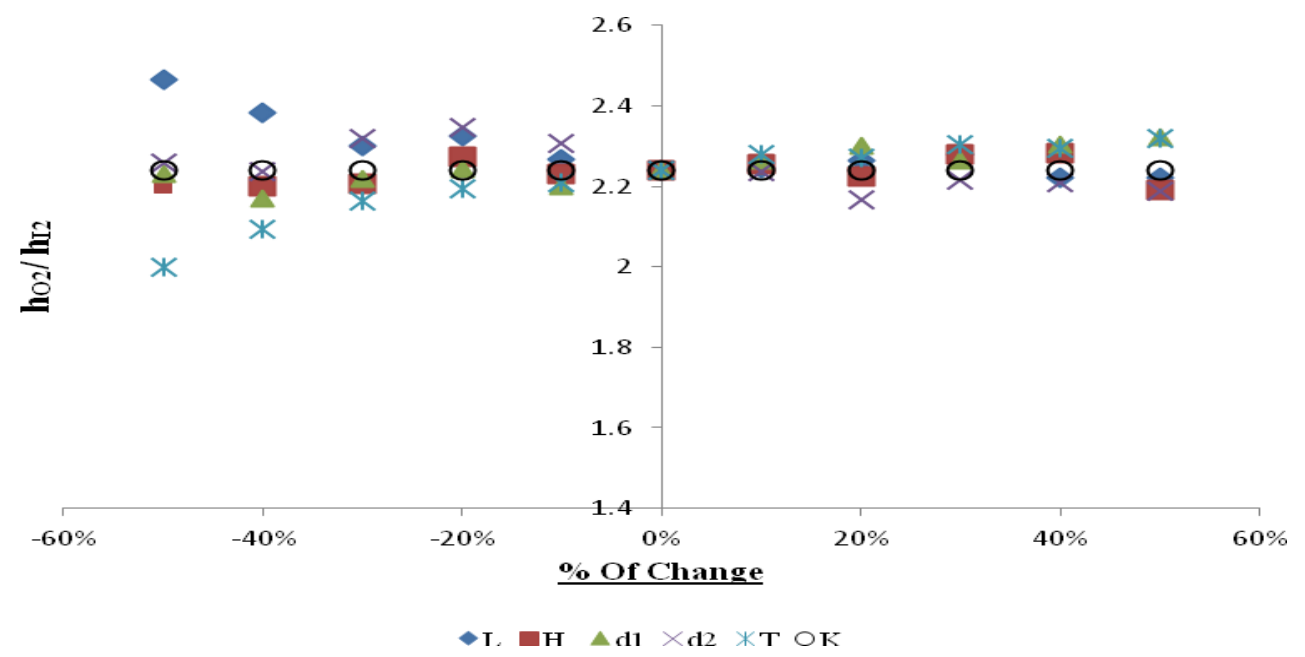

Figure 8. Effect of each variable on the ratio $\left(\mathrm{h}_{\mathrm{O} 2} / \mathrm{h}_{\mathrm{I} 2}\right)$. 
$\frac{h_{O 1}}{h_{I 1}}=a+b \frac{d_{1}}{d_{2}}$

where $a, b$ are coefficients depending on $T / d_{2}$. The value of $a$ and $b$ are given in the Table 1 .

So, the general empirical head loss equation along the U.S. sheet pile could be presented as follows:

$$
\begin{aligned}
\frac{h_{O I}}{h_{I 1}} & =2.18+0.005 \frac{T}{d_{2}} \frac{d_{1}}{d_{2}} \\
& +0.006 \frac{T}{d_{2}}-0.184 \frac{d_{1}}{d_{2}}
\end{aligned}
$$

Plotting the ratio of the head loss along the outer and the inner face for the D.S. sheet pile $\left(\left(\mathrm{h}_{\mathrm{O} 2} / \mathrm{h}_{\mathrm{I}}\right)\right.$ against the depths ratio of U.S. and the D.S. sheet pile $\left(d_{1} / d_{2}\right)$ for different values of $(\mathrm{L} / \mathrm{T})$ is shown in (Fig. 10). It is noticed that $\left(\left(h_{\mathrm{O} 2} / h_{12}\right)\right.$ decreases with the decrease of $\left(\mathrm{d}_{1} / \mathrm{d}_{2}\right)$ for all values of $(\mathrm{L} / \mathrm{T})$. That means the efficiency of the inner face of the D.S. sheet pile improves by $1-3 \%$ with decreasing the ratio $\left(\mathrm{d}_{1} / \mathrm{d}_{2}\right)$. Moreover, comparing the $\mathrm{h}_{\mathrm{O} 2} / \mathrm{h}_{\mathrm{I} 2}$ values at the same depth ratio values, we can conclude that as $(\mathrm{L} / \mathrm{T})$ values increase the $\left(\left(\mathrm{h}_{\mathrm{O} 2} / \mathrm{h}_{\mathrm{I} 2}\right)\right.$ values decrease by $2-4 \%$.

From Fig. 10, it was found that the best relation between $\left(h_{\mathrm{O} 2} / h_{12}\right)$ and $\left(\mathrm{d}_{1} / \mathrm{d}_{2}\right)$ is given by linear equation with correlation equal $R$.

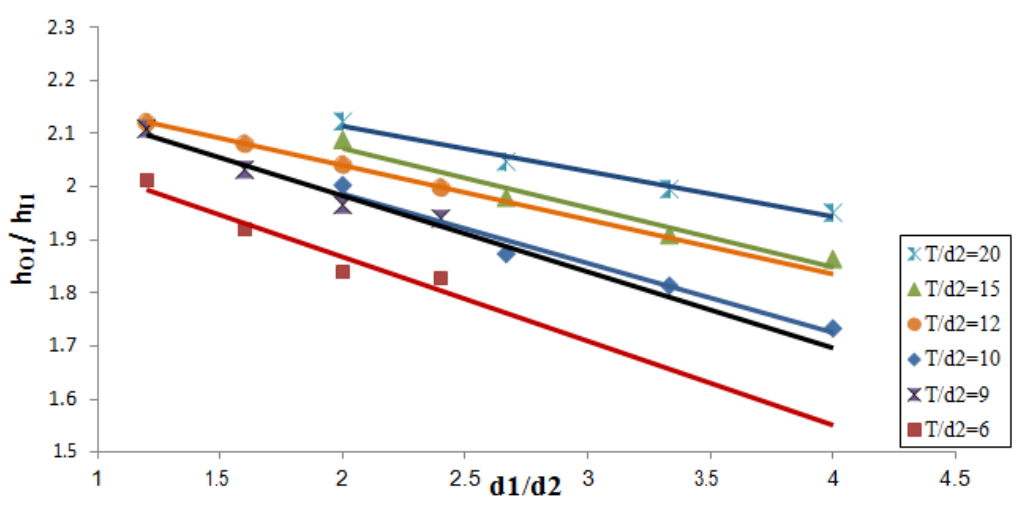

Figure 9. Design chart for the ratio between the head lost along the outer and the inner faces of U.S sheet pile.

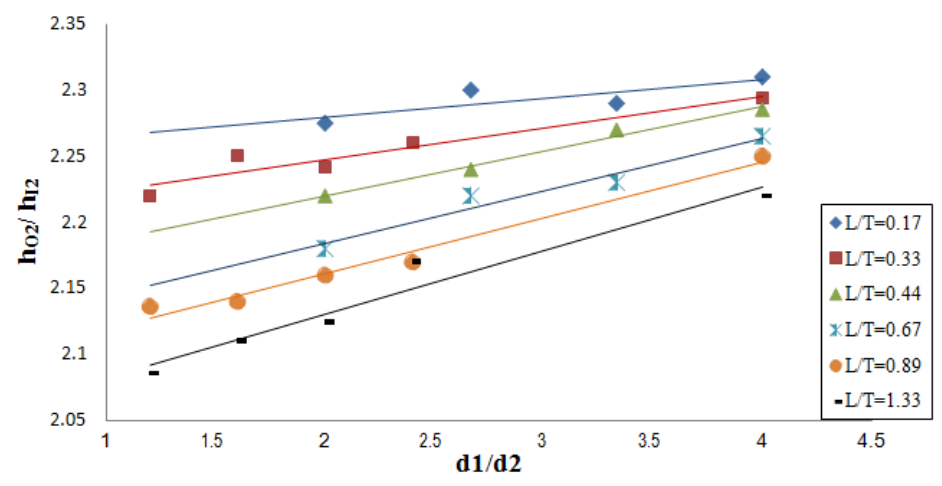

Figure 10. Design chart for the ratio between the head lost along the outer and the inner faces of D.S sheet pile.

Table 1. The value of a and $b$ constants.

\begin{tabular}{ccccccc}
\hline $\mathbf{T} / \mathbf{d}_{2}$ & $\mathbf{6}$ & $\mathbf{9}$ & $\mathbf{1 0}$ & $\mathbf{1 2}$ & $\mathbf{1 5}$ & $\mathbf{2 0}$ \\
\hline $\mathrm{a}$ & -0.16 & -0.14 & -0.13 & -0.1 & -0.11 & -0.09 \\
$\mathrm{~b}$ & 2.2 & 2.26 & 2.24 & 2.24 & 2.3 & 2.28 \\
$\mathrm{R}$ & 0.92 & 0.96 & 0.97 & 0.99 & 0.96 & 0.98 \\
\hline
\end{tabular}


$\frac{h_{O 2}}{h_{I 2}}=c+e \frac{d_{1}}{d_{2}}$

where c, e are coefficients depending on $\mathrm{L} / \mathrm{T}$.

The value of $\mathrm{c}$ and $\mathrm{e}$ are given in the Table (2). So, the general empirical head loss equation along the D.S sheet pile could be presented as follows:

$$
\begin{aligned}
\frac{h_{O 2}}{h_{I 2}} & =2.251+0.027 \frac{L}{T} \frac{d_{1}}{d_{2}} \\
& -0.181 \frac{L}{T}+0.016 \frac{d_{1}}{d_{2}}
\end{aligned}
$$

For the studied variables range, the ratio $\left(h_{\mathrm{O} 1} / h_{11}\right)$ for the upstream sheet pile ranges from 1.55 to 2.15 , and the ratio $\left(\mathrm{h}_{\mathrm{O} 2} / \mathrm{h}_{\mathrm{I}}\right)$ for the downstream sheet pile ranges from 2.08 to 2.3 .

\section{Conclusion}

SEEP2D is implemented to study the actual head loss along the sheet piles fixed at the ends of an apron of a heading up structure. The following main conclusions may be drawn:

- For the U.S. sheet pile, the variables, which have the biggest effect on the head loss ratio along both of its faces, are the thickness of pervious soil layer (T) and the depth of U.S. sheet pile $\left(\mathrm{d}_{1}\right)$.

- For the D.S. sheet pile, the thickness of pervious soil layer $(\mathrm{T})$, the apron length (L) and the depth of D.S. sheet pile $\left(\mathrm{d}_{2}\right)$ have the biggest effect on the head loss ratio.

- The outer and inner faces of the sheet piles do not have the same weight for estimating the creep length. Actually, the creep length along the inner face of the U.S. pile is about $55 \%$ of its supposed value and for the D.S. pile is about $45 \%$ of its supposed value for most of the tests ranges.

- Increasing the sheet pile depth ratio $\left(d_{1} / d_{2}=4\right)$ improves the efficiency of the inner face of the U.S. sheet pile by 8$16 \%$.
- The improvement of the D.S. sheet pile efficiency by decreasing $\mathrm{d} 1 / \mathrm{d} 2$ or increasing $\mathrm{L} / \mathrm{T}$ is small. So, it is better to increase the sheet pile depth ratio to improve the efficiency of the U.S. sheet pile, although it undermines the downstream sheet pile efficiency by small amount.

- Design equations for the actual head loss along the outer and inner faces for both the upstream and downstream sheet piles are driven. These equations may be used as a tool in practical design for aprons of heading up structures formed on pervious soil and provided with upstream and downstream sheet piles at the ends of the apron.

\section{Conflict of Interest}

The authors declare no conflicts of interest.

\section{Funding}

No funding was received for this project.

\section{References}

AboulAtta N, Ezizah G, Yousif N, Anas D (2010), Study of the efficiency of downstream blanket in heading-up structures. Nile Basin Water Science and Engineering 3(1): 79-89.

Aboulatta N, Ezizah G, El Molla D (2014), Modelling seepage effects in heterogeneous soil under heading-up structures using an experimental and numerical methodology. Ph.D. Thesis, faculty of engineering, Ain Shams University, Cairo, Egypt.

Ahmed AA, Ellboudy AM (2010), Effect of sheet pile configuration on seepage beneath hydraulic structures. ASCE, International Conference on Scour and Erosion (ICSE-5) San Francisco, California, United States.

Ahmed AA (2011), Design of hydraulic structures considering different sheet pile configurations and flow through canal banks. Computers and Geotechnics 38(4): 559-565.

Anas D, Gad MA, Samy G, AboulAtta N (2012), A comparative analysis between electric and numerical seepage modeling techniques. The Seventh conference on Environmental Hydrology, American Society of Civil Engineers (ASCE), Cairo, Egypt.

Eftekhar, Afzali S, Barani GA (2013), Application of the seep 3D software in 
modeling the effects of cutoff walls on the reduction of the seepage pressure and exit hydraulic gradient under hydraulic structure. Water Engineering Journal 5(15): 79-90.

El Molla AM (2001), New trend for evaluating the percolation length under aprons of hydraulic structures provided with cut-off and founded on isotropic soil. CERM, Faculty of Engineering, Al -Azhar University 23(1).

El Tahan AM, El-Molla AM (2013), Effects of cut-offs depth ratio on uplift and efficiency of front and back faces of upstream cut-off. 21 $1^{\text {st }}$ CSCE Canadian Hydrotechnical Conference, Alberta, Canada.

Ezizah GMS, El-Molla AM, Abdellateef M, and El-Niazy Hammad M (2000), Seepage under hydraulic structures founded on complex formations. Ph.D. Thesis, Faculty of Engineering, Ain Shams University, Cairo, Egypt (this for ratios).

Gad MA, Anas D, Atta NA, Samy G (2016), Worth of the 3D simulation of seepage in the vicinity of heading-up structures. KSCE Journal of Civil Engineering 20 (2): 679-686.

Guerra P, Priestley D, Fredlund M (2012), 3D groundwater seepage analysis of a levee intersection. Canadian Dam Association (CDA) Annual Conference.
Harr ME (1962), Groundwater and seepage. McGraw- Hill, New York.

Kamble RK, Muralidhar B, Hanumanthappa MS, Patil AV, Edlabadkar JS (2014), Multiple approaches to analyse and control seepage in hydraulic structures", ISH Journal of Hydraulic Engineering, 20(1): 7-13.

Koltuk S, Iyisan R (2013), Numerical analysis of groundwater flow through a rectangular cofferdam. Electronic Journal of Geotechnical Engineering (EJGE), 18.

Noori BMA, Ismaeel KhS (2011), Evaluation of seepage and stability of duhok dam. AlRafidain Engineering Journal 19(1).

Ozkan S (2003), Analytical study on flood induced seepage under river levees. Ph.D Dissertation, Louisiana State University, The Department of Civil and Environmental Engineering.

SEEP2D Primer (1998), Brigham young University, Engineering Computer Graphics Laboratory.

Serge Leliavsky (1965), Design of dams for percolation and erosion. Volume III, Oxford and IBH Publishing Co.

U.S. Army Corps of Engineers, Washington DC (1986), Seepage analysis and control for dams. Engineer Manual 1110-1901. 